\title{
The Continuity and Discontinuity of the Austro-Hungarian and Czechoslovak Solution to the Minority Issue
}

\author{
RenÉ Petráš *
}

\begin{abstract}
The issues of continuity and discontinuity are rather complex in case of the minorities' legal status. The main focus of the paper is the transition from the monarchy to the republic in 1918. During the first Czechoslovak Republic (1918-1938) the legal status of minorities was substantially influenced by the traditions from the period of monarchy as these were used by the new state. The most extensive legal regulation of minorities' status in Czech history existed in interwar Czechoslovakia.
\end{abstract}

Keywords: Austro-Hungarian Monarchy, Czechoslovakia, League of Nations, interwar period, national minorities

\section{INTRODUCTION}

For the Austro-Hungarian Monarchy and interwar Czechoslovakia, the national issue had an existential significance. These days they are referred to as national minorities but at the time of monarchy it might have been more appropriate to refer to them as non-dominant nations. Czechoslovakia assumed the legal system of the monarchy with no significant changes. For minorities, it was quite different. The conceptual aspects that influence continuity in the legal regulation of minorities are explored in this paper. ${ }^{1}$

The transition from the monarchy to the republic was complicated. Czechoslovakia took over the existing legal system but the laws on national minorities could no longer be applied. The situation was relatively confusing in the first years of the republic, but the enactment of the Constitution and the Language Act of 29 February 1920 contributed to a certain stabilization and stability was reached between 1926 and 1928. In any case, a much more detailed legislation was enacted compared to the previous period, mainly in the use of language before the authorities, the so-called language law was created. At the same time, the use of languages in the education strongly followed the practice of the monarchy.

A significant discontinuity was also reflected by the laws on minority status were fundamentally influenced by international law. Even the Czechoslovak Republic was subject to international law on protecting minorities under the supervision of the League of Nations. Some norms contained in the Little Treaty of Saint Germain were supposed to have absolute precedence over national law. This was a shocking situation for lawyers at the time. The jump between the monarchy and the republic was crucial for the regulation of the national issue.

\section{SPECIFIC ASPECTS OF THE LEGAL STATUS OF MINORITIES}

The legal status of minorities features several specific aspects that complicate the whole issue. We are not always aware of these peculiar deviations. A typical feature of law is its relative versatility on the one hand and traditionalism on the other. For example, the law of

\footnotetext{
* Charles University, Prague, petras@prf.cuni.cz.

1 For details refer to Kuklík and Petráš (2017).
} 
the Roman Empire is still the foundation of private law in the prevailing continental legal culture. Yet, constitutional law, the branch encompassing the laws on minority issue, does not have a tradition going back to ancient Rome. The concept of human rights and state power originated at the end of $18^{\text {th }}$ century and inspired most democracies. Analogous institutions exist, such as the parliament, government, and ministries. Even electoral periods are of comparable lengths, we have similar definitions of individual human rights, etc.

Sometimes, those interested in the laws on minority issue are appalled by the fundamental differences between countries, as well as frequent rapid changes even in one territory. The author remembers how surprised he was by a solution system in Switzerland. ${ }^{2}$ The differences are extraordinary in the legislation but also in terminology and especially in the overall concept. Legislation on minorities is often made up of specific provisions that can be understood only after thorough study. The country's traditions also must be taken into account. Sometimes the researcher may also overlook the fact that certain laws (or even the legal practice) can impact the members of minorities more significantly. For example, the interwar land reforms had a fundamental effect on the Germans and the Hungarians living in Czechoslovakia .

Four concepts of legal framework can be distinguished ${ }^{3}$ even if it is more of a stimulus to debate:

1. Zero regulation system: There is no legal regulation of minority status for two possible common causes:

a) The country (traditionally typical of France or the United States) does not recognize their existence. All citizens are equal who have to use the official language in public affairs. Even children can usually speak only in the official language in schools. Giving rights for minorities would violate the equality before the law.

b) Some states essentially ignore the existence of nationalities (e.g. Czechoslovakia between 1945-1960 or rather 1968).

2. Declaratory system: The state usually declares the equality of nations in the constitution, but other legislation is very limited and non-systematic. In Cisleithania (Austria), the regulation was enshrined in Article 19 of the Act No. 142/1867 of the Austrian R.G.Bl., and the lack of further regulation contributed to the chaos and politicization of the issue. For example, the famous struggle for Badeni's regulation at the end of the $19^{\text {th }}$ century. In Switzerland, the minimum regulation traditionally works well.

3. Detailed regulation system: It is possible to say that in these states, classic legal regulation on the status of national minorities is applied. Some provisions are in constitutional laws, others are contained in general laws, and some in subordinate legislation (decrees and regulations). However, two subtypes can be distinguished:

a) These laws are not systematic and there is no uniform national law - just in the case of interwar Czechoslovakia. A typical problem is that a lot of the implementing legislation envisaged by constitutional laws is issued late or not at all.

b) Some states are trying to create a systematic law that would be summarized in some minority rights code. This is what the first Czechoslovak Republic attempted by introducing the so-called national status as a key concession to the Sudeten Germans in 1938. Some rather problematic examples have been enforced in Czech lands (Constitutional Act No. 144/1968 Sb., or the current law applicable in the Czech Republic - Act No. 273/2001 Sb.).

\footnotetext{
2 Petráš (2009a) 397-410.

3 Petráś (2012) 36-46.
} 
4. Autonomous system: In some countries, there are autonomous or federal units where national minorities can themselves pass off legislation to a certain degree. It is necessary to distinguish between constitutional law and actual practice. For example, according to the formal wording of the constitutions, the USSR was a very loose federation, but in reality it was a totalitarian state under the absolute control of the centralised party.

The legal frameworks for addressing the status of national minorities are evolving dynamically. This also leads to remarkable leaps, when the legislation changes over a short period of time substantially. It is possible to use the example of the changes in the territory of Czech lands in the last century from 1918 to 2001, when at least seven completely different legal concepts existed, often with different terminologies! There was a rather minimalist approach during the era of the Austro-Hungarian Monarchy from the point of view of the legal regulation, where the Austrian legal system fundamentally differed from the existing Hungary system. Next came the detailed and partially complicated system of the first Czechoslovak Republic (i.e. Czechoslovakia between 1918-1938), featuring a distinctly different (and practically non-functioning) legal solution in the first two years of statehood and interesting attempts before the Munich Agreement.

Unfortunately, then came the Nazi regime promoting the inequality of people. At that time, laws were enacted that stripped the Jewish population from their fundamental rights. After liberation in 1945, the previous legal framework regulating the status of national minorities ceased to exist. The numbers of minority populations changed substantially. In 1930, the official statistics reported 7.4 million Czechs, 2.3 million Slovaks, 3.3 million Germans, and 0.6 million Hungarians living in Czechoslovakia, in the year 1950 there were 8.4 million Czechs, 3.2 million Slovaks, and only 0.2 million Germans and 0.4 million Hungarians. ${ }^{4}$ Until 1968, the legislation was almost completely absent and minority policy was based only on secret internal guidelines and party documents. In 1968, a special constitutional law was created but it had no major impact on the practice. After 1989, there was a lack of interest in this issue, and the legislation, as originally envisaged by the 1991 Charter, was enacted only in 2001. Yet, it is a rather strange compromise.

Therefore, the issue of continuity and discontinuity has a different dimension in minority law. For example, civil codes had survived the wars and the Nazi era, and they existed even during the craziest experiments of communist regimes. In the case of legal regulation of the status of minorities, literally anything is possible, sometimes even much more is possible! The definition of national minorities in interwar Czechoslovakia provides a good example, where a different definition was used for the purposes of census (essentially a subjective system based on choice) and for more important administrative practices (essentially an objective system, where the use of a minority language convinced the official that it was the mother tongue of the person).

\section{CONTINUITY OF AUSTRIA-HUNGARY AND CZECHOSLOVAKIA IN THE SOLUTION TO THE ISSUE OF NATIONALITIES}

The main focus of the paper is minorities in general. However it has to be emphasized that the formerly fundamental issue of religions had lost its importance in Central Europe as early as the $18^{\text {th }}$ and $19^{\text {th }}$ century. After 1848 , it has been replaced with strong nationalism. The key role was taken by national minorities instead of religious minorities. The issue of 
the continuity of the legal status of national minorities, or rather non-dominant groups, which is a more appropriate term for the period, manifested itself in a peculiar way already at the end of monarchy. At that time, Vienna granted some rights to the Czechs but many of the promises were not fulfilled. A substantial part of the Czech national movement argued for the long-term continuity of the Czech state, which they claimed had never ceased to exist. Therefore, the Czechs, with the tradition of their own state, deserved more rights. This so-called Czech state right, which may be surprising nowadays and which, at the time, was ridiculed and also had numerous contemporary analogies in Europe e.g., Croatia (part of Hungary), Finland (part of Russia) and some regions of Spain. Hence, historic arguments became crucial in nationalism as early as in the $19^{\text {th }}$ century. History was also the key social science of that era and it was not by accident that a famous historian, František Palacký, was acknowledged as father of the Czech nation for decades. ${ }^{5}$

There were fundamental differences in the legal status of non-ruling nations in Cisleithania and Hungary, which were caused by long-term differences in legal development. In the Czech lands, the origins of law regarding national (mostly language) question go back to the Estates period (approximately 1420-1620), where it concerned almost exclusively the language law and its impact on the gradually decreasing importance of the Latin and the growing role of the Czech language. The Czech language became suppressed in the period of absolutism (1620-1848). The issue of language played a key, if not absolute role, in this development and this situation persisted to a certain extent also in later periods including the era of the First Czechoslovak Republic (1918-1938). Latin remained the official language in the Hungarian state much longer than in the Czech lands owing in particular to the country's diverse nationalities. ${ }^{6}$

The most important laws governing the status of minorities in the last 50 years preceding the establishment of the Czechoslovak Republic were adopted almost immediately after creation of the Dual Monarchy in 1867. The basis for the status of minorities was completely different in the two parts of Austria-Hungary. In Cisleithania, the legal regulation of minorities' status was minimal and therefore, open to various solutions. The national order in Hungary was codified rather minutely in the Act on Nationalities (No. 44/1868), which was often not applied in practice though. It did, however, lay a legal basis for the efforts of minorities in Hungary to improve their status when they strove to enforce its application

In Cisleithania, the nationality law was based on a brief provision of Article 19 of the Universal Civil Rights Act No. 142/1867 of the Austrian R.G.Bl., part of the so-called December Constitution:

Paragraph 1 All nations in the state have equal rights and each nation has an inviolable right to keep and cultivate its own nation and language. Paragraph 2 An equal right of all languages common in the state to be used in schools, authorities and public life is recognised by the state. Paragraph 3 In lands where multiple nations reside public schools shall be established so that each nation has proper means to be instructed in its own language without being forced to learn another language of the land.

\footnotetext{
5 Petráš (2006) 694-740.

6 Sobota (1927) 6-7, 13-14.
} 
In theory, Article 19 may be understood as the legal basis for the complete equality of nations in the monarchy. However, the actual situation was different. The interpretation of this provision provoked major disputes until the very end of the monarchy. The main question was whether the rule was directly applicable or whether it was just a declaratory provision that must be enacted into a special law before being applied in practice. ${ }^{7}$

The laws on national minorities enacted in the period of monarchy were not maintained and the legal framework implemented in Czechoslovakia was fundamentally different. Generally, the first law of the newly formed state, the so-called Reception Act, took over the former legal order and administrative organisation, but the legal state of national minorities was to be regulated differently. The legal solution evolved gradually in the $1920 \mathrm{~s}$, and the first months of the republic saw often rather peculiar legal experiments. The Czechoslovak concept of the legal regulation of national minorities was different in nature and mainly was considerably more detailed. It was most prominent in the language law which was in Cisleithania in many respects unregulated and often debatable, while Czechoslovakia adopted the Language Act in 1920 and a detailed language decree in 1926. In a way the language law as branch of the legal system was created by the republic. Generally, the interwar republic took over the law from the period of monarchy and changed it only exceptionally as in the case of minorities. The legal status of minorities was even based on a completely new concept. Logically the republic learned its lessons from the deficiencies of the legal regulation of the period of monarchy, and many specific provisions were a reaction to that negative experience. ${ }^{8}$

The legal status of the national minorities was significantly influenced in the first Czechoslovak Republic by the international protection of minorities under the auspices of the League of Nations. In the interwar period, the League of Nations oversaw the creation of an extensive system which at least de iure instituted many minorities' rights in some countries (especially in central and eastern Europe). All minority treaties and declarations under the supervision of the League of Nations were very similar, except for some details. The content may be divided into three basic parts. First, the rights guaranteed for all citizens; second, provisions on acquiring citizenship which formed a prerequisite for the third most important part of the treaties dealing with the rights of citizens who differed from the majority by race, language, or religion - i.e., the rights of minorities. ${ }^{9}$

The minority treaty for the Czechoslovak Republic was the "Treaty Between the Principal Allied and Associated Powers and Czechoslovakia signed in Saint-Germain-enLaye on 10 September 1919' (included in the Collection of Laws of the Czechoslovak Republic under No. 508/1921). In its main provision, the Czechoslovak Republic undertook “.... to recognise [its stipulations] as fundamental laws, and that no law, regulation or official action shall conflict or interfere with these stipulations, nor shall any law, regulation or official action prevail over them" (Article 1 of the Treaty). It was a rather problematic undertaking as it conferred precedence to the treaty over national laws, including constitutional ones. Interwar legal experts were basically unable to agree on the issue of relation to the law of the Czechoslovak Republic as well as on the numerous debatable elements of the interpretation. In practice, the international undertaking was discharged in the Czechoslovak Republic by integrating similar provisions into laws (most frequently

\footnotetext{
7 For more detail see Petráš (2009b) 278-79.

8 Kučera (1999) 154-70. Petráš (2010a) 485-514.

9 Temperley (1921) 112-46. Thornberry (1992) 41-50. Petráš (2000) 31-40.
} 
constitutional acts): Title IV of the Constitution, the Constitutional Act on State Language, the Act to Regulate Acquisition of Citizenship.

In the interwar period, there was a considerable difference between the theory and practice of minority protection, i.e., between the rules of international law and their actual application. The practical protection was subject to heavy political influence where the actual international situation took precedence over law. On the other hand, in the period of its operation the system of protection created by the League of Nations was truly functional and despite various weaknesses it was rather active: e.g., the procedure for dealing with complaints, or petitions, submitted by minorities to the League of Nations, the inspection by the members of the minority section of the Secretariat of the League, etc. ${ }^{10}$

The law of the first Czechoslovak Republic regulating the legal state of national minorities and nationality can be divided into a general part and a special part within which the branches of language law, national law dealing with schooling and culture, and the specific issue of autonomy may be distinguished. The language law in particular was a relatively stable institution and as the most extensive, as a detailed branch of the minority law, it attracted the most interest from legal experts. The legal status of national minorities was also influenced by rules that cannot be directly classified as nationality or minority law. ${ }^{11}$

During the first republic, the legal status of minorities and the law in general was based on the Constitutional Charter of 1920. Most provisions dealing with minorities were concentrated in title VI 'Protection of National, Religious and Racial Minorities', ss. 128134. The majority of the legal provisions were literally adopted from the Minority Treaty. The protection of nations and affiliation to nations represented an important aspect of the minorities' status. Criminal protection was primarily provided in section 14 of the Protection of the Republic Act (No. 50/1923). ${ }^{12}$ Additionally, for example section 3 of the Act on Industrial Committees (No. 330/1921) protected workers or employees against discharge where such discharge was due to inter alia affiliation to national or religious community or organisation.

Many legal rules were important for minorities despite regulating completely different matters than nationality law. These included the laws on land reform because the land owners affected most fundamentally were in the vast majority members of minorities. Other legal rules influencing the status of minorities include the Act on the relationship between Prague Universities (No. 135/1920), whereby the Czech (rather than the German) university gained the prestige of being 'the successor of the old higher learning institution' which provoked a major national unrest despite having no material significance; the Act on Public Holidays and Commemorative Days (No. 65/1925) and many others. ${ }^{13}$ Some legal rules were basically to the advantage of the minorities in that they guaranteed actual equality for example in terms of the composition of public bodies and the suffrage.

The language law had been of key importance for the issue of nationalities since the period of monarchy. Before the establishment of the Czechoslovak Republic, the Czech language was usually one of the languages allowed in the relations between the authorities and the citizens (external official language), whereas the exclusive status of the German language as the internal official language (or the language used while working in the office

10 Gütermann (1979) 149; Walters (1965) 405-09; Peoples (1993) 82-85, 255.

11 Sobota (1933-1934) 222-24.

12 Klepetař (1937) 188-200.

13 Spiegel (1920) 68-84. 
or for communication between the authorities themselves) was maintained. The language law during the first republic was based on the Act on the Main Principles of Language Law in the Republic of Czechoslovakia of 29 February 1920 (No. 122/1920) (in the following: Language Act of 1920). ${ }^{14}$ Section 1 of this act provided that 'The Czechoslovak language is the official state language of the republic (under Article 7 of the Treaty Between the Principal Allied and Associated Powers and Czechoslovakia signed in Saint-Germain-enLaye on 10 September 1919).' When laying down the principles of language law, the legislators took into consideration the obligations of the Czechoslovak Republic arising from the Minority Treaty. The Language Act of 1920 laid down primarily the right of the minorities to use the mother tongue in communication with the authorities and courts in districts where the minority represented more than $20 \%$ of the population, but overall the system was quite complicated. The official language had an exclusive role in internal communication within and between the authorities. However, the regulation was so complex that it generated extensive and often conflicting case law and the state authorities often committed serious mistakes.

The enactment of governmental decrees on the application of the Language Act kept being postponed and therefore, it presented a very serious political issue. The most important law enacted in this regard during the era of the first republic was the Government Decree on Languages No. 17/1926, introducing a particularly complicated regulation on the possibility of members of minorities to communicate with authorities in their own language. If members of minorities addressed state authorities in their language. They could also use the preferred official language. There were three levels of entitlement depending on how numerous the minority was in the given district. Overall the minority law was rather complex and awkward in practical application which caused primarily pedantic favouring of the official language - only a member of the minority was allowed to use their language in communication with the authorities, providing that the minority constituted at least $20 \%$ of population in the district. All the other citizens had to use the official language even if they might have preferred to use a minority language e.g., German. ${ }^{15}$

The laws on education and culture of minorities was mostly taken over from the period of monarchy. In particular, the citizens took a major interest in minority education system over the whole period of first republic, which offered teaching in other language than the official one. The issue could be observed from the point of view of the German population mostly. Even before 1918, the Germans had the best schooling system which is why state funding was provided to the education system of other nationalities, which was sometimes perceived by the Germans as discriminatory. Nonetheless, the quality of the Germans' education (funded from public resources) was high and was even gradually growing. Germans, being the only example in this regard, had even higher education institutions at their disposal. Overall, the schools were of very good quality and the vast majority of pupils could attend schools offering instruction in their mother tongue. The weakness consisted in material reduction in self-government in education compared to the period of monarchy. ${ }^{16}$

One of the most important demands of minorities, mostly of the Germans, was autonomy in interwar Czechoslovakia. Autonomy has been discussed in various contexts now as well as at the time of the first republic and not only politicians but also legal experts

14 Sobota (1926); Epstein (1927) 47-136.

15 Kural (1991) 37.

16 Kocích (1979) 159-62. 
understand the concept sometimes widely and at other times very narrowly. The interwar Czechoslovak Republic contemplated the introduction of so-called cultural-personal autonomy which made it possible for the minorities to govern some matters autonomously - usually education, culture, etc. ${ }^{17}$ The law of the first Czechoslovak Republic encompassed some minor elements of cultural autonomy and therefore some researchers ${ }^{18}$ claim that autonomy existed de facto. The establishment of the Czechoslovak Republic also provided for real autonomy - for the territory of Carpathian Ruthenia. The Czechoslovak Republic agreed to create this autonomy in the Minority Treaty, however it was not implemented until the Munich Agreement. The concept of autonomy was related to the concept of territorial self-government. There were efforts to carry out administrative reforms which would have created new large administrative units ('zhupas' or regions). In some of these, the minorities would have represented the majority of the population. Extensive selfgovernment of such new units would then form the basis of a kind of territorial autonomy. The Regional Act (the 'zhupa' act) was never implemented and efforts to carry out such administrative reform failed. ${ }^{19}$

\section{FURTHER DEVELOPMENT IN CONTINUITY OF LEGAL STATUS OF MINORITIES IN CZECHOSLOVAKIA}

The most extensive legal regulation of minorities' status in Czech history existed in interwar Czechoslovakia, however this is far from the end of this complicated development. The Nazi occupation caused another major discontinuity in legal regulation. After the liberation, the changes made to laws during the occupation were rejected and the system was supposed to return to the state that existed before the Munich Agreement. It is, however, impossible to completely disregard the peculiar legal development of that period. ${ }^{20}$ The atrocities of occupation made Czech society, as well as some experts in Western countries, to conclude that the coexistence with minorities represents an issue that may be resolved only by strong and severe interventions. The Nazi legal concept is remarkable and shocking, because the principle of legal equality became one of the cornerstones of legal development since the turn of $18^{\text {th }}$ and $19^{\text {th }}$ century and the rights of minorities analysed here represent one of the few exceptions to this rule. From the beginning of the occupation in March 1939, the Nazis divided citizens into three groups: the privileged Germans as the citizens of the Reich, Czechs as the citizens of the protectorate and the severely discriminated groups, mostly the Jews. These groups were governed by specific laws in many legal areas, which means that the modern principle of territorial law was replaced by a peculiar form of return to personal law.

The intention was not only the formal elimination of the principle of legal equality, but also to justify extermination. In the Czech lands, the Jewish and Roma populations were almost completely exterminated. However, the Nazis also planned to destroy the Czech nation - in part by extermination and in part by Germanization. In the Slovak State created in March 1939 and strongly dependent on Germany, the situation of minorities was complex. The German minority benefited from various advantages and the regime did not dare to intervene against the Hungarians. However, the Jews mostly fell victim to the

\footnotetext{
17 Peška (1933) 9-10, 26-29; Chmelař (1937) 92-95.

18 Malý (1991) 272-74.

19 For more detail see Petráś (2003) 197-228.

20 Kuklík (2002).
} 
Holocaust. It was curious that Slovakia paid the Nazis for the transport of Jews, in particular to Auschwitz. ${ }^{21}$

Generally, the liberation meant a return to the legal regulation before the Munich Agreement in accordance with the decree on reinstatement of the previous legal order, yet there were many important exceptions, such as recognition of the existence of Slovak bodies (especially Slovak National Council) created during the war and a major change in the attitude towards minorities. The interwar Czechoslovak Republic ranked among the states having the best attitude toward minorities but the post-war Czechoslovak Republic reversed its course and implemented a hostile policy with the objective of crushing nonSlavonic minorities. Furthermore, there were also discussions about the displacement of the Polish minority. The traditional German minority, which represented approximately $30 \%$ of the population, was gradually replaced as the largest non-Czech group in Czech lands by the Slovaks, who were close in terms of language and represented according to various post-war censuses only $2-4 \%$ of the population and did not have majority in any of the regions. Interwar legal regulations, such as the constitutional Language Act of 1920, was considered obsolete.

Unexpected elements of continuity and discontinuity may be found in the status of national minorities during the communist era. The establishment of the regime in 1948 presented several specific features from the point of view of minorities. While the citizens' civil rights were quickly restricted as a whole, the rights of the most important minorities, i.e., the Hungarians and the remaining Germans, were quickly reinstated. At the beginning of the 1950s, the minority rights of Hungarians were renewed even though it had no support in legal regulations. The 1960 Constitution, which in general, represented the worst deterioration of Czechoslovak constitutionalism but had at least a brief provision on minorities as opposed to the 1948 Constitution did not say a word about the minorities forming a considerable part of the population. ${ }^{22}$

1968 is particularly important from the perspective of the minorities' status. Efforts to introduce reforms were suppressed by the Soviet invasion and the 'normalisation regime' was worse than the liberal one of the 1960s. However two important constitutional laws survived, which were prepared before 1968 invasion. ${ }^{23}$ The Constitutional Act No. 143/1968 $\mathrm{Sb}$. regulating federalisation, and the Constitutional Act on Status of Nationalities No. $144 / 1968 \mathrm{Sb}$. were adopted just before the fiftieth anniversary of establishment of the Republic. The envisaged laws, which would have enforced these concepts, were not adopted, even though the latter constitutional law represents one of the most remarkable legal regulations relating to minorities. It is not very extensive but is the first separate list of the rights of minorities. ${ }^{24}$

The fall of the communist regime in 1989 did not change the formal status of minorities at the beginning. In 1991, the new Charter of Fundamental Rights and Freedoms repealed the 1968 Constitutional Act. Minorities therefore lost their own Constitutional Act which is often a sensitive issue during periods of strong nationalism. Furthermore the Charter contains a more concise legal regulation compared to the 1968 Constitutional Act. The Charter was then assumed without any changes by the Czech Republic. It took until 2001 for the implementing legislation to be passed. The new Minority Act No. 273/2001 Sb. is

21 Petráš (2007) 84-88.

22 Petráš (2007). Rataj (2003) 177-78. Petráš (2010b) 60-68.

23 Jičínský (1990) 14-15. Rychlík (1997) 225-26.

24 Petráš (2004) 240-80. 
considered awkward and its application has many deficiencies. ${ }^{25}$ Fortunately, since the displacement of Germans, the minority issue has attracted little interest in Czech lands. Therefore, such marginalisation of minorities' status that could have resulted in dangerous incidents in the interwar Czechoslovak Republic, threatening Central European peace, did not cause any major issues. However, in Slovakia the minority issue has remained sensitive and potentially dangerous up to the present day.

\section{SUMMARY}

The issues of continuity and discontinuity are rather complex in case of the minorities' legal status because most individual countries have their own approach. Remarkably different concepts appeared during the various time periods even in the same territory as in the case of Czech lands.

The main focus of the paper is the transition from the monarchy to the republic in 1918. During the first Czechoslovak Republic (1918-1938) the legal status of minorities was substantially influenced by the traditions from the time period of monarchy as similar concepts were used by the new state. This involved not only the reception of legal rules which were gradually changed, but also the assumption of certain methods and attitudes e.g., tense relations between Czechs and Germans. For instance, the passing of basic laws including the Constitution by Parliament, without the representation of minorities (November 1918 to March 1920), was to a considerable extent influenced by negative experiences involving obstructions in the Austrian Parliament as well as the absolute disintegration of regional self-government in Bohemia between 1908 and 1913.

During the monarchy, when planning reforms (for example in administration) circumvention of Parliament by order of the monarch or the executive was considered and the relationships among nations and the political situation of the period should not be idealised. The willingness to accept the autonomy of minorities or federation in Czechoslovakia was hindered by the previous bad experience with the operation of the composite Austro-Hungarian state. During the republic, there were for example tragic incidents in March 1919, when dozens of Germans were killed. However there was also national unrest with casualties during the monarchy.

The author disagrees with those who claim that maintaining the monarchy, with its centuries of tradition, would have prevented national conflicts. Relations between nations during the first Czechoslovak Republic (1918-1938) were in principle similar to those from the preceding period of the monarchy. However, the legal solution was very different, so there was continuity in fact, but major discontinuity in law.

\section{LITERATURE}

Chmelař, J., National Minorities in Central Europe (Orbis 1937).

Epstein, L., Das Sprachenrecht der Tschechoslowakischen Republik (Gebrüder Stiepel 1927).

Gütermann, Ch., Das Minderheitenschutzverfahren des Völkerbundes (Duncker \& Humblot 1979).

Jičínský, Z., Vznik České národni rady v době pražského jara 1968 a jeji působení do podzimu 1969

(Constitution of the Czech National Council During the Prague Spring 1968 and its Activities until Autumn 1969) (Svoboda 1990).

25 Petráš (2010). 
Klepetař, H., Seit 1918... (Julius Kittls Nachfolger 1937).

Kocích, M., 'Poznámky k právní úpravě školské, osvětové a spolkové činnosti národnostních menšin v buržoasní ČSR' ('Notes on Legal Regulation of the Activities of National Minorities in Education, Culture and Associations in the Bourgeois Czechoslovak Republic') in Sbornik praci z dějin státu a práva (Collection of Papers on the History of the State and the Law) (Praha 1979) 155-71.

Kučera, J., Minderheit im Nationalstaat (Oldenbourg 1999).

Kuklík, J., Mýty a realita tzv. Benešových dekretù (Myths and Reality of the so-called Beneš Decrees) (Linde 2002).

Kuklík, J. and Petráš, R., Minorities and Law in Czechoslovakia 1918-1992 (Karolinum 2017).

Kural, V., 'Jazykový problém a jazykové právo v ČSR 1918-1938 z hlediska česko-německého' ('The Language Issue and the Language Law during the Czechoslovak Republic 1918 - 1938 from Czech - German Perspective') (1991) 89 Slezský sborník 32-38.

Malý, K., 'Sprache - Recht und Staat in der tschechischen Vergangenheit' in Sprache - Recht Geschichte (Müller 1991) 257-81.

Peoples and Minorities in International Law (Martinus Nijhoff 1993)

Peška, Z., Kulturní samospráva národnich menšin (Cultural Self-Government of the National Minorities) (Orbis 1933).

Petráš, R., 'Mezinárodněprávní ochrana menšin po první světové válce' ('International Legal Protection of Minorities after the World War I') (2000) 11 Historický obzor 31-40.

Petráš, R., 'Minderheiten in der Zwischenkriegs-Tschechoslowakei - ihre rechtliche und faktische Stellung' (2003) 10 Historica / Historical Sciences in the Czech Republic 197-228.

Petráš, René, 'Menšiny v Československu 1945-1989' ('Minorities in Czechoslovakia 1945-1989') in Vývoj práva v Ceskoslovensku v letech 1945-1989 (Development of the Law in Czechoslovakia between 1945-1989) (Karolinum 2004) 240-80.

Petráš, R., 'Národní otázka v českých zemích na sklonku monarchie' (The National Issue in Czech Lands at the End of Monarchy) in Vývoj české ústavnosti v letech 1618-1918 (Development of Czech Constitutionality between 1618 and 1918) (Karolinum 2006) 694-740.

Petráš, R., Menšiny v komunistickém Československu (Minorities in Communist Czechoslovakia) (Eurolex 2007).

Petráš, R., ‘Švýcarská specifika řešení národnostní otázky’ ('Swiss Specific Aspects of Solving National Issues') in Petráš, R., Petrův, H. and Scheu, H. (eds), Menšiny a právo v České republice (Minorities and the Law in the Czech Republic) (Auditorium 2009a) 397-410.

Petráš, R., Menšiny v meziválečném Československu (Minorities in Interwar Czechoslovakia) (Karolinum 2009b).

Petráš, R., 'Práva národnostních menšin v justiční a správní praxi' ('Rights of National Minorities in Judicial and Administrative Practice') in Československé právo a právní věda v meziválečném období (1918-1939) a jejich misto ve střední Evropě 1 (Czechoslovak Law and Jurisprudence in the Interwar Period (1918-1939) and its Role in Central Europe 1) (Karolinum 2010a) 485-514.

Petráš, R., 'Constitutional Development in Czechoslovakia in the 1960s and Problems of Ethnicity' in Czech Law between Europeanization and Globalization (Karolinum 2010b) 60-68.

Petráś, R. et al., Aktuální problémy právního postavení menšin v České republice (Current Issues of Legal Status of Minorities in the Czech Republic) (Úřad vlády ČR 2010c).

Petráś, R., Cizinci ve vlastní zemi. Dějiny a současnost národnostního napětí v Evropě (Foreigners in their Own Country: History and Present of National Tension in Europe) (Auditorium 2012).

Rataj, J., KSČ a Československo I. (1945-1960) (The Czechoslovak Communist Party and Czechoslovakia I) (Oeconomica 2003).

Rychlík, J., Češi a Slováci ve 20. století / Česko-slovenské vztahy 1945-1992 (Czechs and Slovaks in the 20th Century / Czecho-Slovak Relations 1945-1992) (AEP - Ústav TGM 1997).

Sobota, E., Výklad našeho jazykového práva (The Interpretation of Our Language Law) (Svěcený 1926).

Sobota, E., Národnostní právo československé (Czechoslovak Nationality Law) (Barvič Novotný 1927).

Sobota, E., 'K pojmu národnostního práva' ('On the Concept of Nationality Law') (1933-1934) 4 Národnostní obzor 222-24. 
Spiegel, L., Verfassungsoktroi und Sprachengesetz (Deutsche Zeitung 1920).

Temperley, H. W. V., A History of the Peace Conference of Paris V (IIA 1921).

Thornberry, P., International Law and the Rights of Minorities (Clarendon 1992).

Walters, F. P., A History of the League of Nations (OUP 1965). 